\title{
ASAS PRIMUM REMEDIUM DALAM PENEGAKAN HUKUM PIDANA DI BIDANG LINGKUNGAN HIDUP
}

\author{
Muslim, Dosen Fakultas Syariah dan Hukum UIN Suska Riau \\ Email: muslimkhansa72@gmail.com
}

\begin{abstract}
Environmental protection and management is systematic and integrated effort made to preserving environmental functions and prevent pollution, damage, maintenance, supervision, and law enforcement. In law No. 32 of 2009 environmental criminal law enforcement is known as one of the primum remedium principles. Identification of the problems is first, what is ment by the principle of primum remedium in law No. 32 of 2009, second how important in the application of the primum remedium principle in the context of optimizing criminal law enforcement in the environmental field. The research method is descriptive analytical, with normative juridical approach. Law No. 32 of 2009 on Environmental Protection and Management in enforcing its criminal provisions emphasizes the application of premature remedium principles in enforcing environmental criminal law.
\end{abstract}

\section{Keywords: Living environment, Primum Remedium, Criminal law enforcement.}

\begin{abstract}
Abstrak
Perlindungan dan pengelolaan lingkungan hidup adalah upaya sistematis dan terpadu yang dilakukan untuk melestarikan fungsi lingkungan hidup dan mencegah terjadinya pencemaran, kerusakan, pemeliharaan, pengawasan dan penegakan hukum. Dalam Undang undang Nomor 32 Tahun 2009 penegakan hukum pidana lingkungan dikenal salahsatu asas primum remedium. Identifikasi masalahnya adalah : pertama, Apakah yang dimaksud dengan asas primum remidium dalam Undangundang Nomor 32 Tahun 2009, kedua, Bagaimana pentingnya penerapan asas primum remedium dalam rangka optimalisasi penegakan hukum pidana dibidang lingkungan. Tujuan penulisan ini untuk mengetahui bagaimana pentingnya penerapan asas primum remedium dalam rangka optimalisasi penegakan hukum pidana dibidang lingkungan. Metode penelitiannya adalah deskriptif analitis, dengan pendekatan yuridis normatif. Undang- undang Nomor 32 Tahun 2009 dalam menegakkan
\end{abstract}


ketentuan pidananya lebih menekankan penerapan asas premium remedium dalam penegakan hukum pidana.

Kata Kunci : Lingkungan Hidup, Primum Remidium, Penegakan hukum Pidana

\section{Pendahuluan}

Lingkungan Hidup yang baik dan sehat merupakan hak asasi setiap warga negara Indonesia sebagaimana yang diamanatkan dalam Pasal 28 H Undang-undang Dasar 1945 yang berbunyi:

"Setiap orang berhak hidup sejahtera lahir dan bathin bertempat tinggal dan mendapatkan lingkungan yang baik dan sehat serta berhak memperoleh pelayanan kesahatan".

Perlindungan lingkungan hidup merupakan suatu masalah yang harus dipertimbangkan dari aspek global. Oleh karena itu, negara, pemerintah dan seluruh pemangku kepentingan berkewajiban untuk melakukan perlindungan dan pengelolaan lingkungan hidup dalam pelaksanaan pembangunan berkelanjutan agar lingkungan hidup Indonesia dapat tetap menjadi sumber dan penunjang hidup bagi rakyat Indonesia serta makhluk hidup lain.

Pasal 1 angka 1 Undang-undang Nomor 32 Tahun 2009 tentang Perlindungan dan Pengelolaan Lingkungan Hidup merumuskan perlindungan dan pengelolaan lingkungan hidup sebagai upaya sistematis dan terpadu yang dilakukan untuk melestarikan fungsi lingkungan hidup dan mencegah terjadinya pencemaran dan/atau kerusakan lingkungan hidup yang meliputi perencanaan, pemanfaatan, pengendalian, pemeliharaan, pengawasan dan penegakan hukum. ${ }^{1}$

Masalah lingkungan hidup berupa pencemaran dan perusakan lingkungan hidup di Indonesia khususnya dan dunia pada umumnya pada saat sekarang ini, yang meliputi lingkungan tanah dan hutan, lingkungan

1 Penjelasan Umum Undang-undang Nomor 32 Tahun 2009 tentang Perlindungan dan Pengelolaan Lingkungan Hidup. 
air maupun lingkungan udara adalah masalah yang harus ditangani secara serius baik dari segi pencegahannya maupun penegakan hukumnya.

Satjipto Rahardjo mengatakan penegakan hukum merupakan satu usaha untuk mewujudkan ide-ide dan konsep-konsep menjadi kenyataan. Penegakan hukum adalah suatu proses untuk mewujudkan keinginankeinginan hukum menjadi kenyataan. Keinginan-keinginan hukum adalah pikiran-pikiran badan pembuat undang-undang yang dirumuskan dalam peraturan-peraturan hukum. ${ }^{2}$

Dalam asas hukum pidana modern termasuk dalam pidana lingkungan hidup dikenal 2 (dua) asas yang banyak digunakan hingga saat ini, yaitu ultimum remedium dan primum remedium. Ultimum remedium merupakan upaya penerapan hukum pidana sebagai jalan terakhir ketika instrumen hukum lainnya tidak efektif untuk mengurangi suatu tindak pidana. Sedangkan primum remedium merupakan upaya penerapan hukum pidana sebagai alat utama untuk menimbulkan efek jera baik bagi pelaku suatu tindak pidana maupun bagi semua orang agar tidak akan melakukan suatu tindak pidana. Menurut Eddy O.S. Hiariej apa yang dikemukakan beberapa ahli, seperti Muladi, Merkel tentang ultimum remedium pada intinya sama, bahwa hukum pidana merupakan hukum terakhir yang digunakan jika instrumen hukum lainnya tidak dapat digunakan atau tidak dapat berfungsi sebagaimana mestinya. ${ }^{3}$ Sedangkan primum remedium merupakan teori hukum pidana modern yang menyatakan bahwa hukum pidana sebagai alat utama dalam penegakan hukum. Oleh karena itu perlu dianalisis lebih mendalam pengaturan teori atau aliran hukum pidana lingkungan hidup di Indonesia saat ini.

Kemajuan zaman yang ditandai dengan pesatnya investasi dari berbagai negara, persaingan global yang semakin sengit dan berkembangnya industri dan teknologi telah meningkatkan peran korporasi

2 Satjipto Rahardjo, Penegakan Hukum, Suatu Tinjauan Sosiologis, Yogyakarta, Genta Publishing, 2009, hlm.24.

${ }^{3}$ Eddy O.S Hieriej, Prinsip-Prinsip Hukum Pidana, (Yogyakarta: Cahaya Atma Pustaka, 2016. hlm..33. 
tidak hanya kepada pengusaha, pekerja dan konsumen namun juga kepada pertumbuhan ekonomi nasional. Peran korporasi yang paling dirasakan manfaatnya yaitu peningkatan penerimaan negara dari korporasi, membuka lapangan kerja yang sangat besar, dan pioneer bagi produksi dan pemanfaatan teknologi yang sangat membantu pekerjaan manusia. Namun diantara besarnya peran korporasi terhadap pembangunan negara masih terdapat perbuatan pelanggaran hukum pidana di bidang lingkungan hidup. Untuk memahami pelanggaran hukum pidana tersebut maka sangat perlu dikaji secara mendalam tentang bentuk pertanggungjawaban pidana korporasi di bidang lingkungan hidup. Pada era globalisasi dewasa ini, eksistensi suatu korporasi memiliki andil yang cukup besar baik bagi kepentingan manusia ataupun negara yaitu meningkatkan penerimaan negara, menciptakan lapangan pekerjaan dan alih teknologi. Namun sering juga diikuti oleh perbuatan melanggar hukum termasuk pelanggaran hukum pidana.

Penerapan asas Primum Remedium dalam Rangka Mencegah Tindak Pidana Lingkungan Hidup Sanksi hukum bidang lingkungan hidup terdapat 3 (tiga) jenis yakni sanksi hukum Administrasi, Keperdataan, dan Kepidanaan. Dalam penyelesaian sengketa lingkungan hidup, maka dikedepankan sanksi administrasi. Sanksi Administrasi yang terdapat dalam Undang-undang Nomor 32 Tahun 2009 tentang Perlindungan dan Pengelolaan Lingkungan Hidup di Pasal 76 sampai Pasal 83. Penerapan sanksi administrasi ini menyangkut pada perizinan, dan izin-izin lingkungan hidup dikeluarkan oleh pemerintah pusat, dan pemerintah daerah. Pemerintah pusat dimaksud adalah Menteri, sedangkan pemerintah daerah adalah Bupati/ Walikota. Ketentuan Umum Pasal 1 Undang-undang Nomor 32 Tahun 2009 tentang Perlindungan dan Pengelolaan Lingkungan Hidup, ayat (37) menyebutkan, Pemerintah Pusat, yang selanjutnya disebut Pemerintah, adalah Presiden Republik Indonesia yang memegang kekuasaan pemerintahan Negara Republik 
Indonesia sebagaimana dimaksud dalam Undang-undang Dasar 1945. Di Pasal 1 ayat (38) berbunyi:

"Pemerintah daerah adalah Gubernur, Bupati, atau Walikota, dan perangkat daerah sebagai unsur penyelenggara pemerintah daerah, sedangkan di ayat (39) disebutkan: Menteri adalah menteri yang menyelenggarakan urusan pemerintahan di bidang perlindungan dan pengelolaan lingkungan hidup. Sanksi Administrasi ini yang didahulukan sebelum sanksi hukum lingkungan lainnya'.

Meskipun telah memenuhi unsur delik materiil. Rumusan Delik materiil ini sebagaimana diatur dalam Pasal 98 ayat (1) dan Pasal 99 ayat (1) dan Pasal 100 sampai Pasal 109. ${ }^{4}$ Secara praktek walaupun dalam delik materiil terpenuhi tetapi peran hukum administrasi yang diutamakan atau didahulukan dan didorong menyelesaikan masalah lingkungan. Setelah upaya tersebut tidak efektif, maka hukum pidana didayagunakan atau dioptimalkan. Dengan demikian, fungsi hukum pidana terhadap delik materiil adalah premium remedium. Hukum pidana sebagai pelengkap atau komplemen dari hukum administrasi atau perdata atau mediasi. Terhadap kesalahan pelaku relatif berat dan/atau akibat perbuatannya relatif besar dan/atau perbuatannya menimbulkan keresahan masyarakat, maka hukum pidana bukan lagi ultimum remedium akan tetapi sudah primum remedium. ${ }^{5}$

Posisi primum remedium dalam konteks hukum bukan lagi sebagai obat terakhir melainkan sebagai obat pertama untuk membuat jera orang melakukan pelanggaran yang bersifat pidana. Undang undang terkait pengelolaan lingkungan hidup, Undang-undang Nomor 4 Tahun 1982 atau UULH, Undang-undang Nomor 23 Tahun 1997 atau UUPLH dan Undang-undang Nomor 32 Tahun 2009 atau UUPPLH telah memuat

\footnotetext{
${ }^{4}$ Akib Muhammmad, Hukum Lingkungan Perspektif Global dan Nasional, Raja Grafindo Persada, Jakarta, 2013, hlm. 169.

5 Syahrul Machmud, Problematika Penerapan Delik Formil dalam Perspektif Penegakan Hukum Pidana Lingkungan Hidup di Indonesia, Penerbit Mandar Maju, Bandung, 2012. hlm. 5.
} 
ketetentuan yang tegas mengenai sanksi administratif, sanksi perdata maupun sanksi pidana. Penerapan azas ultimum remedium dan primum remedium, terdapat pada Undang-undang Nomor 4 Tahun 1982 atau UULH, Undang-undang Nomor 23 Tahun 1997 atau UUPLH maupun Undang-undang Nomor 32 Tahun 2009 atau UUPPLH, namun terdapat perbedaan pengaturan dan penerapan asas ultimum remedium ataupun primum remedium dalam Undang-undang Nomor 4 Tahun 1982 atau UULH, Undang-undang Nomor 23 Tahun 1997 atau UUPLH dengan Undang- undang Nomor 32 Tahun 2009 atau UUPPLH. Undang-undang Nomor 4 Tahun 1982 atau UULH dan Undang-undang Nomor 23 Tahun 1997 atau UUPLH lebih menekankan penerapan asas ultimum remedium sedangkan Undang-undang Nomor 32 Tahun 2009 atau (UUPPLH) lebih menekankan asas primum remedium dalam penegakan hukum lingkungan. Dengan demikian dalam kerangka operasionalisasi hukum pidana dikaitkan dengan asas ultimum remedium jauh lebih tegas dibandingkan operasionalisasi asas subsidairitas pada Undang-undang Nomor 32 Tahun 2009 atau (UUPPLH). Hanya saja UUPPLH sangat membatasi dengan delik formil (yang berkaitan dengan hukum administrasi) tertentu saja, padahal masih banyak delik formil lain namun justru hukum pidana didayagunakan secara primum remedium. ${ }^{6}$

Berdasarkan uraian latar belakang masalah tersebut, maka dapat dirumuskan permasalahan dalam penulisan ini, pertama, Apakah yang dimaksud dengan asas primum remedium dalam Undang-undang Nomor 32 Tahun 2009. Kedua, Bagaimanakah penerapan asas primum remidium dalam rangka optimalisasi penegakan hukum pidana di bidang lingkungan hidup. Penulisan ini bertujuan untuk mengetahui dan memahami mengenai prinsip primum remidium dalam rangka optimalisasi penegakan hukum pidana di bidang lingkungan hidup. Diharapkan

${ }^{6}$ Syahrul Mahmud, Penegakan Hukum Lingkungan Indonesia, Penegakan Hukum Administrasi, Hukum Perdata, dan Hukum Pidana Menurut Undang Undang No. 32 Tahun 2009, Graha IImu, Yogyakarta, 2011, hlm. 236. 
penelitian ini bermanfaat bagi masyarakat umum, peneliti, mahasiswa, advokat dan dosen sebagai referensi dalam penelitian selanjutnya.

\section{Kajian Pustaka}

Emil Salim secara umum merumuskan lingkungan hidup diartikan sebagai segala benda, kondisi, keadaan dan pengaruh yang terdapat dalam ruangan yang kita tempati dan mempengaruhi hal yang hidup termasuk manusia di dalamnya. Batas ruang lingkungan menurut pengertian ini bisa sangat luas, namun untuk praktisnya kita batasi ruang lingkungan dengan faktor-faktor yang dapat dijangkau oleh manusia seperti faktor alam, faktor politik, faktor ekonomi, faktor sosial dan lain-lain. ${ }^{7}$ Dominasi perusak lingkungan hidup adalah manusia dengan teknologi modern sehingga kerusakan lingkungan hidup cepat dan masif.

Pengertian pencemaran dan kerusakan lingkungan hidup tertuang dalam Undang-undang Nomor 32 Tahun 2009tentang Perlindungan dan Pengelolaan Lingkungan Hidup, didalam ketentuan Umum Pasal 1 ayat (14), menyebutkan,

"Pencemaran lingkungan hidup adalah masuk atau dimasukkannya mahluk hidup, zat, energi, dan/atau komponen lain ke dalam lingkungan hidup oleh kegiatan manusia sehingga melampaui baku mutu lingkungan hidup yang telah ditetapkan".

Selain itu, menyangkut perusakan lingkungan hidup di ayat (16) berbunyi:

"perusakan lingkungan hidup adalah tindakan orang yang menimbulkan perubahan langsung atau tidak langsung terhadap sifat fisik, kimia, dan/atau hayati lingkungan hidup sehingga melampaui kriteria baku kerusakan lingkungan hidup".

${ }^{7}$ Nico Ngani, Metodologi Penelitian dan Penulisan Hukum, Penerbit Pustaka Yustisia, Jakarta, 2012, hlm. 71. 
Terhadap kesalahan pelaku relatif berat dan/ atau akibat perbuatannya relatif besar dan/ atau perbuatannya menimbulkan keresahan masyarakat, maka sanksinya adalah hukum pidana bukan lagi ultimum remedium akan tetapi sudah primum remedium. Asas Pidana "Primum remedium" (obat utama) adalah teori hukum pidana modern yang menyatakan bahwa hukum pidana sebagai alat utama dalam penegakan hukum. Asas pidana "Primum Remedium" dalam kasus hukum pidana dapat dikatakan sebagai satu-satunya hal yang dapat dilakukan kecuali dengan menerapkan hukum pidana tersebut, tidak ada alternatif lain sebagai dasar atau fondasi untuk menegakkan suatu hukum. Primum remedium berarti tidak ada alternatif penyelesaian lain kecuali hukum itu sendiri. ${ }^{8}$

\section{Metode Penelitian}

Penelitian ini merupakan suatu penelitian yuridis normatif, yaitu penelitian hukum yang dilakukan dengan cara meneliti dan menelaah bahan-bahan pustaka atau data sekunder. Penelitian ini dilakukan dengan mengkaji bahan-bahan hukum primer, sekunder ataupun tersier. Bahan hukum primer yang digunakan adalah perundang-undangan nasional. Bahan hukum sekunder berupa, buku- buku teks, hasil penelitian, jurnal, tulisan-tulisan ilmiah dan bahan-bahan bacaan lainnya. Bahan-bahan yang telah dihimpun selanjutnya dianalisis dengan menggunakan metode analisa kualitatif.

${ }^{8}$ https://punyamimpi.wordpress.com/2018/02/05/tentang-primum-remedium-danultimum-remedium-dalam- hukum-pidana. 


\section{Hasil dan Pembahasan (Asas Premium Remedium dalam undang-undang Nomor 32 Tahun 2009 tentang Perlindungan dan Pengelolaan Lingkungan Hidup).}

Asas Pidana "Primum remedium" (obat utama) adalah teori hukum pidana modern yang menyatakan bahwa hukum pidana sebagai alat utama dalam penegakan hukum. Asas pidana "Primum Remedium" dalam kasus hukum pidana dapat dikatakan sebagai satu-satunya hal yang dapat dilakukan kecuali dengan menerapkan hukum pidana tersebut, tidak ada alternatif lain sebagai dasar atau fondasi untuk menegakkan suatu hukum. Primum remedium berarti tidak ada alternatif penyelesaian lain kecuali hukum itu sendiri. ${ }^{9}$ Peraturan perundang-undangan yang merupakan perwujudan salah satu upaya melindungi dan menyelematkan lingkungan hidup. Undang-undang Nomor 32 Tahun 2009 Tentang Perlindungan Dan Pengelolaan Lingkungan Hidup, merupakan peraturan payung (umbrella act) bagi peraturan sektoral lainnya yang mengatur lingkungan hidup.

Undang-undang Nomor 32 Tahun 2009 lebih menekankan pada penerapan asas Primum Remedium dalam penegakan hukum pidana lingkungan. Dalam Udang-undang Nomor 23 Tahun 1997 berlakunya ketentuan hukum pidana memperhatikam asas Ultimum Remedium artinya penegakan hukum pidana merupakan upaya terakhir bilamana penegakan hukum administrasi perdata ataupun alternatif penyelesaian sengketa lingkungan hidup tidak efektif. Penegakan hukum pidana dapat bersifat Primum Remedium, bilamana salah satu diantara ketiga hal berikut terjadi :

a. Apabila tingkat kesalahan pelaku reletif berat;

b. Apabila akibat perbuatan dari pelaku relatif besar; dan

\footnotetext{
${ }^{9}$ Masrudi Muchtar, SH.,MH, Sistem Peradilan Pidanas di Bidang Perlindungan dan Pengelolaan Lingkungan Hidup, PT. Prestasi Pustaka Jakarta, Jakarta, 2015, hlm. 177.
} 
c. Apabila perbuatan pelaku menimbulkan keresahan masyarakat.

Berkaitan dengan sifat, fungsi, dan tujuan hukum pidana, masalah pengaturan sanksi pidana dalam peraturan perundang-undangan, dikenal apa yang disebut dengan istilah Ultimum remedium dan Primum remedium. ${ }^{10}$ Dalam prinsip ultimum remedium yang tercantum dalam Undang-undang Nomor 4 Tahun 1982 dan Undang-undang Nomor 23 Tahun 1997 dinyatakan sanksi pidana sebagai sanksi terakhir, setelah sanksi perdata dan sanksi administratif. Sedangkan dalam Undangundang Nomor 32 Tahun 2009, prinsip Primum remedium sanksi pidana dipergunakan sebagai senjata utama atau yang pertama kali diancamkan dalam suatu ketentuan undang-undang. Sanksi hukum pidana yang tajam inilah yang membedakan dengan sanksi-sanksi dalam hukum-hukum yang lain.

Sanksi hukum bidang lingkungan hidup terdapat 3 (tiga) jenis yakni sanksi hukum Administrasi, Keperdataan, dan Kepidanaan. Dalam penyelesaian sengketa lingkungan hidup, maka dikedepankan sanksi administrasi. Sanksi Administrasi yang terdapat dalam Undang-undang Nomor 32 Tahun 2009 di Pasal 76 sampai Pasal 83. Penerapan sanksi administrasi ini menyangkut pada perizinan, dan izin- izin lingkungan hidup dikeluarkan oleh pemerintah pusat, dan pemerintah daerah. Pemerintah pusat dimaksud adalah Menteri, sedangkan pemerintah daerah adalah Bupati/ Walikota. Ketentuan Umum Pasal 1 Undang-undang Nomor 32 Tahun 2009, ayat (37) menyebutkan, Pemerintah Pusat, yang selanjutnya disebut Pemerintah, adalah Presiden Republik Indonesia yang memegang kekuasaan pemerintahan Negara Republik Indonesia sebagaimana dimaksud dalam Undang-Undang Dasar. Demikian,fungsi hukum pidana terhadapdelik materiil adalah premium remedium. sebagai pelengkap atau komplemen dari hukum administrasi atau perdata atau mediasi. Terhadap kesalahan pelaku relatif berat dan/atau akibat perbuatannya relatif besar

\footnotetext{
${ }^{10} \mathrm{Ibid}$. hlm. 178.
} 
dan/atau perbuatannya menimbulkan keresahan masyarakat, maka hukum pidana bukan lagi ultimum remedium akan tetapi sudah primum remedium. $^{11}$

Penegakan hukum pidana lingkungan tetap memperhatikan asas ultimum remedium yang mewajibkan penerapan penegakan hukum pidana sebagai sebagai upaya terakhir setelah penerapan penegakan hukum administrasi dianggap tidak berhasil. Penerapan asas ultimum remedium ini hanya berlaku bagi tindak pidana fromil tertentu, yaitu pemidanaan terhadap pelanggaran baku mutu air limbah, emisi, dan gangguan. Prinsip umum yang tertuang dalam dalam KUHP, menyatakan tiada suatu perbuatan dapat dipidana kecuali atas kekuatan aturan pidana dalam perundang-undangan (principle of legality). ${ }^{12}$ Artinya apabila suatu perbuatan yang melawan hukum telah diatur dalam peraturan perundangundangan, maka perbuatan tersebut harus diberi sanksi dipidana. Penerapan asas ultimum remedium dalam penyelesaian perkara lingkungan hidup tersebut tidak "pro" lingkungan hidup, bahkan akan memperlemah dalam usaha untuk melindungi dan menyelematakan lingkungan hidup. Penyelesaian perkara lingkungan hidup di pengadilan dengan mendasarkan asas ultimum remedium ini dapat „membelenggu“hakim dalam penyelesaian perkara lingkungan hidup di pengadilan. Dampak dari penerapan asas "ultimum remedium", maka perkara lingkungan hidup yang diajukan ke pengadilan akan ditolak kalau belum diselesaiakan melaui intrumen administrasi terlebih dahulu tetapi langsung mengajukan tuntutan dengan istrumen pidana. Hal ini tentu sebagai hambatan dalam memberikan perlindungan dan penyelamatan lingkungan hidup melaui instrument pidana dan tidak mendatangkan efek jera bagi pelaku yang menimbulkan pencemran dan /atau kerusakan

\footnotetext{
${ }^{11}$ Syahrul Machmud, Op.Cit, hlm. 5.

12 Ibid, hlm. 123.
} 
lingkungan hidup. Asas ultimum remedium ini jika dikaitkan dengan prinsip umum dalam hukum pidana bertentangan dengan Asas Legalitas. ${ }^{13}$

Asas legalitas tercantum dalam Pasal 1 ayat (1) KUHP,yang berbunyi: "Tiada suatu perbuatan dapat dipidana kecuali atas kekuatan aturan pidana dalam perundang-undangan yang telah ada, sebelum perbuatan dilakukan". ${ }^{14}$ Artinya ketika ada peraturan perundangundangan yang mengatur tentang suatu tindak pidana, maka terhadap orang yang melanggar aturan tersebut berdasarkan asas legalitas harus dipidana, demikian pula dengan yang diatur dalam Pasal 100 Undangundang Nomor 32 Tahun 2009. Dalam Pasal 100 ayat (1) tersebut sudah jelas rumusan tindak pidana dan hukuman yang diterima bagi orang yang melanggar pasal tersebut, dan jika dikaitkan dengan asas legalitas maka ketika ada yang melanggar Pasal tersebut seketika itu pula pidana berjalan, ditambah dengan tindak pidana dalam Pasal 97 UndangUndang Nomor 32 Tahun 2009 tentang Perlindungan dan Pengelolaan Lingkungan Hidup adalah merupakan kejahatan, maka sedikit keliru penulisan kata "pelanggaran" dalam pasal 100 ayat (2) Undang-undang Nomor 32 Tahun 2009, yang seharusnya berdasarkan Pasal 97 tindak pidana ini merupakan kejahatan. ${ }^{15}$

Asas legalitas melekat pada Pasal 100 ayat (1), maka pengenaan pidana terhadap pelanggaran pasal tersebut hanya didasarkan pada pasal itu, yaitu pidana penjara paling lama 3 (tiga) tahun dan denda paling banyak Rp3.000.000.000,00 (tiga miliar rupiah), sehingga dalam Pasal 100 ayat (1) sudah jelas bahwa pasal tersebut terdapat ancaman pidana, yang pada akhirnya mempunyai akibat hukum oleh Pasal 100 ayat (1) tersebut ada pidana untuk itu, sehingga tidak mungkin dikesampingkan pidana yang diatur dalam Pasal 100 ayat (1) tersebut oleh Pasal 100 ayat

${ }^{13}$ Imam Budi Santoso, 2018, Penerapan Asas Ultimum Remidium Dalam Penegakan Hukum Pidana Lingkungan Hidup, UBELAJ,Volume 3 Issue I, April 2018. hlm.19.

\footnotetext{
${ }_{15}^{14}$ Andi Hamzah, Hukum Pidana, PT. Sofmedia, Jakarta, 2015, hlm. 49.

${ }^{15}$ Imam Budi Santoso, Op.Cit, hlm. .20.
} 
(2), yang berujung tidak adanya kepastian hukum jika pidana tersebut dijadikan sebagai upaya terakhir tehadap pelanggaran Pasal 100 ayat (1).19 Dengan demikian penggunakan asas"ultimum remedium" yang dapat berujung tidak adanya kepastian hukum dalam penyelesaian perkara lingkungan hidup di pengadilan dan berakibat tidak bisa memberikan perlindungan dan penyelamatan lingkungan hidup, maka menjadi suatu keniscayaan penerapan asas pidana "primum remedium" dalam penyelesaian perkara lingkungan hidup. Penggunaan asas pidana "ultimum remedium" digeser menjadi asas pidana "primum remedium" sebagai dasar penyelesaian perkara lingkungan hidup di pengadilan.

Penerapan suatu instrumen didasarkan pada keefektifan instrumen tersebut dalam menangkal segala pencemaran dan perusakan lingkungan yang terjadi, mengingat bahwa pencemaran dan perusakan lingkungan yang terjadi sudah sedemikian parah maka instrumen hukum pidana dikedepankan menjadi Asas pidana "primum remedium". Dengan perkataan lain pelanggaran atas Undang-undang Nomor 32 Tahun 2009, yang dilakukan oleh individu, masyarakat atau korporasi; dengan ancaman pidana administratif dan sanksi perdata tampaknya tidak membuat jera pelaku-pelaku tindak pidana lingkungan hidup tersebut. Asas yang selama ini dipergunakan yakni asas pidana "ultimum remedium" beralih ke asas "primum remedium".

Penerapan asas primum remedium dalam mekanisme penegakan hukum pidana lingkungan, artinya hukum pidana berada di depan dalam penegakan hukum lingkungan dan dalam hal ini penegakan hukum administrasi dan hukum perdata tetap bisa dilakukan, bahkan bersamaan. Di samping itu, dengan diterapkan prinsip premium remedium dalam mekanisme penegakan hukum pidana lingkungan diharapkan: ${ }^{16}$

1. Dapat memberikan stigma dan pencelaan kepada pelaku yang berfungsi sebagai efek pencegahan sejak dini. Maka niat pelaku bisnis

${ }^{16}$ Lilik Mulyadi, Kompilasi Hukum Pidana Dalam Perspektif Teoritik dan Praktik Peradilan, 2007, Mandar Maju, Bandung, hlm. 56. 
untuk melakukan pencemaran dan perusakan lingkungan hidup demi pertimbangan ekonomi dapat ditekankan; dan

2. Dengan diterapkannya prinsip primum remedium dalam mekanisme penegakan hukum pidana lingkungan ini kita dapat mengharapkan kepada terciptanya rezim anti pencemaran dan perusakan lingkungan hidup di masa akan datang.

\section{Kesimpulan dan Saran}

\section{Kesimpulan :}

1. Asas Primum remedium adalah teori hukum pidana modern yang menyatakan bahwa hukum pidana sebagai alat utama dalam penegakan hukum lingkungan sebagaimana diamanatkan dalam Undang-undang Nomor 32 Tahun 2009 Tentang Perlindungan dan Pengelolaan Lingkungan Hidup, merupakan peraturan payung (umbrella act) bagi terciptanya kelangsungan lingkungan.

2. Optimalisasi penerapan asas premium remedium dalam mekanisme penegakan hukum pidana lingkungan, artinya hukum pidana berada di depan dalam penegakan hukum lingkungan dan dalam hal ini penegakan hukum administrasi dan hukum perdata tetap bisa dilakukan, bahkan bersamaan. Penerapan suatu instrumen didasarkan pada keefektifan instrumen tersebut dalam menangkal segala pencemaran dan perusakan lingkungan yang terjadi, mengingat bahwa pencemaran dan perusakan lingkungan yang terjadi sudah sedemikian parah maka instrumen hukum pidana dikedepankan menjadi Asas pidana "primum remedium". Dengan perkataan lain pelanggaran atas Undang-undang Nomor 32 Tahun 2009, yang dilakukan oleh individu, masyarakat atau korporasi; dengan ancaman pidana administratif dan sanksi perdata tampaknya tidak membuat jera pelaku-pelaku tindak pidana lingkungan hidup. 


\section{Saran}

1. Terhadap kesalahan pelaku kejahatan lingkungan relatif berat dan/atau akibat perbuatannya relatif besar dan/atau perbuatannya menimbulkan keresahan masyarakat, maka hukum pidana bukan lagi ultimum remedium akan tetapi sudah primum remedium.

2. Asas primum remedium dalam konteks hukum pidana lingkungan bukan lagi sebagai obat terakhir melainkan sebagai obat pertama untuk membuat jera orang melakukan pelanggaran yang bersifat pidana. 


\section{DAFTAR PUSTAKA}

\section{Buku-buku:}

Akib Muhammmad, Hukum Lingkungan Perspektif Global dan Nasional, Raja Grafindo Persada, Jakarta. 2013.

Andi Hamzah, Hukum Pidana, Jakarta. 2015.

Eddy O.S Hieriej, Prinsip-Prinsip Hukum Pidana, Cahaya Atma Pustaka Yogyakarta. 2016.

Imam Budi Santoso, Penerapan Asas Ultimum Remidium Dalam Penegakan Hukum Pidana Lingkungan Hidup, UBELAJ. 2018.

Lilik Mulyadi, Kompilasi Hukum Pidana Dalam Perspektif Teoritik dan Praktik Peradilan, Bandung. 2007.

Machmud Syahrul, Problematika Penerapan Delik Formil dalam Perspektif Penegakan Hukum Pidana Lingkungan Hidup di Indonesia, Mandar Maju, Bandung. 2012.

Mahmud Syahrul, Penegakan Hukum Lingkungan Indonesia, Penegakan Hukum Administrasi, Hukum Perdata, dan Hukum Pidana Menurut Undang Undang No. 32 Tahun 2009, Graha Ilmu, Yogyakarta. 2011.

Masrudi Muchtar, Sistem Peradilan Pidana di Bidang Perlindungan \& Pengelolaan Lingkugan Hidup, Prestasi Pustakaraya, Jakarta. 2015.

Nico Ngani, Metodologi Penelitian dan Penulisan Hukum, Pustaka Yustisia, Jakarta. 2012.

Satjipto Rahardjo, Penegakan Hukum, Suatu Tinjauan Sosiologis, Genta Publishing Yogyakarta. 2009.

\section{Internet dan Media Massa}

https://punyamimpi.wordpress.com/2018/02/05/tentang-primum-remediumdan-ultimum-remedium-dalam- hukum-pidana.

\section{Peraturan Perundang-undangan}

Undang-undang Dasar 1945.

Undang-undang Nomor 32 Tahun 2009 tentang Perlindungan dan Pengelolaan Lingkungan Hidup. 